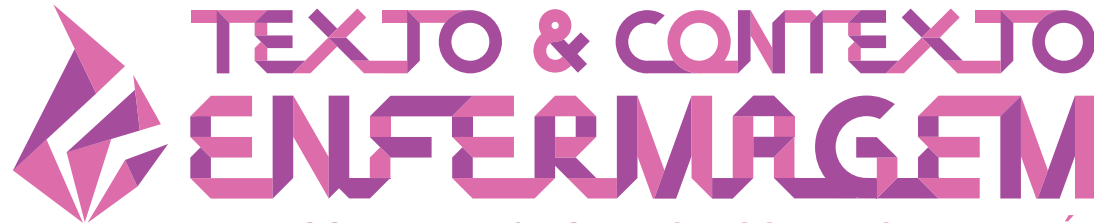

TEXT \& CONTEXT NURSING TEXTO \& CONTEXTO ENFERMERÍA

\section{MEDICAL-DEVICE-RELATED PRESSURE INJURY ON ADULTS: AN INTEGRATIVE REVIEW}

\section{Euni de Oliveira Cavalcanti ${ }^{1}$ Ivone Kamada ${ }^{1}$ (D)}

${ }^{1}$ Universidade de Brasília, Programa de Pós-Graduação em Enfermagem. Brasília, Distrito Federal, Brasil.

\begin{abstract}
Objective: to identify factors associated with medical-device-related pressure injury.

Method: an integrative review of published articles on the subject related to the adult population in the databases of PUBMED, Scopus, MEDLINE, Latin American and Caribbean Health Sciences Literature (Literatura LatinoAmericana e do Caribe em Ciências da Saúde, LILACS), Web of Science and Nursing Database (Banco de Dados em Enfermagem, BDENF), between 2013 and 2018.

Results: medical-device-related pressure injuries were common in adults, especially in the elderly, due to capillary fragility, among other changes. Other observed factors were length of stay, critically ill patients or those requiring any type of medical device. Numerous medical devices have been associated with skin lesions; among the most frequent were breathing, feeding, and orthopedic devices, tubes, oximeters, neck collars, patches and nasogastric tubes.
\end{abstract}

Conclusion: the first step towards prevention is exploration in terms of identifying the types of injury-causing devices and evidence-based interventions, and disseminating information to the entire multidisciplinary team.

DESCRIPTORS: Pressure injury. Pressure ulcer. Medical-device-related pressure ulcer. Equipments and supplies. Adult. 


\section{LESÃO POR PRESSÃO RELACIONADA A DISPOSITIVO MÉDICO EM ADULTOS: REVISÃO INTEGRATIVA}

\section{RESUMO}

Objetivo: identificar fatores associados à lesão por pressão relacionada a dispositivo médico.

Método: revisão integrativa de artigos publicados sobre o tema relacionado à população adulta nas bases de dados da PUBMED, Scopus, MEDLINE, Literatura Latino-Americana e do Caribe em Ciências da Saúde (LILACS), Web of Science e Banco de Dados em Enfermagem (BDENF), entre 2013 e 2018.

Resultados: lesões por pressão relacionadas a dispositivo médico foram comuns em adultos, principalmente em idosos, devido à fragilidade capilar, entre outras alterações. Outros fatores observados foram tempo de permanência, pacientes críticos ou que necessitassem de qualquer tipo de dispositivo médico. Inúmeros dispositivos médicos foram associados às lesões de pele; entre os mais frequentes estiveram dispositivos respiratórios, de alimentação, ortopédicos, tubos, oxímetros, colares cervicais, adesivos e sondas nasogástricas.

Conclusão: o primeiro passo para a prevenção é a exploração, em termos de identificação dos tipos de dispositivos que causam a lesão e intervenções baseadas em evidências científicas, além da divulgação das informações para toda a equipe multiprofissional.

DESCRITORES: Lesão por pressão. Úlcera por pressão. Lesão por pressão relacionada a dispositivo médico. Equipamentos e provisões. Adulto.

\section{LESIÓN POR PRESIÓN RELACIONADA A DISPOSITIVOS MÉDICOS EN ADULTOS: UNA REVISIÓN INTEGRADORA}

\section{RESUMEN}

Objetivo: identificar factores asociados con las lesiones por presión relacionadas a dispositivos médicos.

Método: revisión integradora de artículos publicados sobre el tema relacionado a la población adultas en las siguientes bases de datos: PUBMED, Scopus, MEDLINE, Literatura Latino-Americana e do Caribe em Ciências da Saúde (LILACS), Web of Science y Banco de Dados em Enfermagem (BDENF), entre 2013 y 2018.

Resultados: las lesiones por presión relacionadas con dispositivos médicos fueron comunes en adultos, principalmente en ancianos, debido a la fragilidad capilar, entre otras alteraciones. También se observaron otros factores como tiempo de permanencia, pacientes críticos o que necesitaban cualquier tipo de dispositivo médico. Se asoció un sinnúmero de dispositivos médicos a las lesiones de piel; entre los más frecuentes se pueden mencionar los dispositivos respiratorios, de alimentación y ortopédicos, los tubos, los oxímetros, los collares cervicales, los adhesivos y las sondas nasogástricas.

Conclusión: el primer paso para la prevención es la exploración, en términos de identificar los tipos de dispositivos que causan la lesión y las intervenciones basadas en evidencias científicas, además de divulgar la información a todo el equipo multiprofesional.

DESCRIPTORES: Lesión por presión. Úlcera por presión. Lesión por presión relacionada con un dispositivo médico. Equipamientos y suministros. Adulto. 


\section{INTRODUCTION}

Pressure Injuries (PIs), as well as wounds, have become a major public health problem as an important morbidity and mortality cause, in addition to the major impact on the health of patients, families and society. Even with technological developments and improved prevention techniques, there is still an increase in the prevalence of cases, which encourages research and a deeper investigation of this event, and translates as a quality indicator in the care provided, involving both the interventions incorporated in the treatment, as in the prevention of new cases. ${ }^{1}$

The literature describes a PI as an injury to the skin or underlying tissue, involving mainly bone prominence spots resulting from pressure associated with frictional or shear forces. It is classified into six categories according to its evolution, affected tissue and depth, in addition to categories called non-gradable and suspected deep tissue injury. ${ }^{2-3}$

The National Pressure Ulcer Advisory Panel (NPUAP) has recently refined the definition of the test system for PI, including Medical-Device-Related PIs (MDRPIs). MDRPI was defined as resulting from the use of devices designed and applied for diagnostic or therapeutic purposes. The resulting PI conforms to the device's pattern or shape. ${ }^{4}$

Since patients admitted to intensive care are more prone to PI due to hemodynamic instability, changes in blood circulation, use of vasoactive drugs (which alter skin integrity through peripheral vasoconstriction), among other factors, Pls have been tracked for decades on sacral and heels region, but the incidence or the acquired rates resulting from medical devices are not yet widely reported. However, many institutions have reduced the number of traditional PIs (sacral, buttocks and calcaneus). Thus, the increase in device-related injuries was noticed. ${ }^{5}$

These PIs developed in Intensive Care Units (ICUs) may also be related to the fact that the professionals pay more attention to the patient's pathologies and care with other organs than to the skin. However, it is observed that the patients recover from their illnesses, but some will have to live with the injuries resulting in the hospitalization period, for months or years. Thus, it is essential that the professional assumes his responsibility when the patient develops lesions, observing possible failures occurred in the care provided, aiming at improving the quality of care. ${ }^{6}$

A study conducted in the United States with 104,266 patients on the prevalence of Pls showed a $19.9 \%$ MDRPI rate, while $14.3 \%$ were PIs in the sacral region, $10.2 \%$ in the calcaneus and $8.8 \%$ in the buttocks. In this study, the devices that correlated with the lesion were not described. ${ }^{7}$

The patients with higher risks of MDRPI generation are those with impaired sensory perception, such as neuropathy and communication deficit (oral intubation, language barriers, unconsciousness or nonverbal state). ${ }^{8}$ Therefore, the evaluation and prevention of the PIs are paramount, so that professionals use the systematization of care by means of scales, as a reference to the Braden scale, which is scientifically based on the pathophysiology that involves PI development, allowing the evaluation of aspects inherent to the process of injury generation, addressing six parameters: sensory perception, moisture, mobility and activity, nutrition, friction and shear. ${ }^{9}$

As the term "medical-device-related pressure injury" was included in the new NPUAP guidelines in 2016, research should contribute scientifically to knowledge of the topic and its exploration in the field of nursing and related fields, which provide direct or indirect assistance to ICU patients. PI indicators reveal important points about the provided quality of care.

Thus, this paper purpose was to identify associated factors with MDRPI in the adult population. 


\section{METHOD}

This is an integrative review, developed in six stages: theme identification and elaboration of the guiding question, sampling (definition of inclusion and exclusion criteria), categorization of the studies (definition of the data to be extracted from the selected studies), evaluation of the studies (critical analysis of the selected studies), results interpretation (discussion of the main results) and review/synthesis of knowledge presentation. ${ }^{10}$

For the development of the guiding question and for the definition of the research problem, the PICO method (P: population; I: intervention; C: control or comparison; and O: outcome), which is based on the construction of research questions of a diverse nature, enabling the formulation of a research question that has validity and applicability, based on evidence, to solve current clinical questions. ${ }^{11}$

The theme developed was MDRPIs in adults. The guiding questions of the interviews were the following: What does the literature present about MDRPIs in adults? What research is needed to explain the phenomena of MDRPIs in adults? Thus, P corresponded to adults, I to MDRPI, C to hospital environment and $O$ to publications in the literature on the subject.

Articles were searched through the Central Library system of the University of Brasilia and the CAPES Journal Portal, which provides access to the main national and international databases in various areas. To select the articles, the following databases were used: PUBMED, Scopus, MEDLINE, Latin American and Caribbean Health Sciences Literature (LILACS), Web of Science and Nursing Database (BDENF).

To search the selected articles, the descriptors with the following Boolean operators "Pressure injury" OR "pressure ulcer" AND "medical device" AND "adult" were used, which are contained in the Health Sciences Descriptors (Descritores em Ciências da Saúde, DeCS) and in the Medical Subject Headings $(\mathrm{MeSH})$.

The inclusion criteria were indexed articles published in the last 5 years (between January 2013 and July 2018), due to the consensus on theme updates being released in 2016; and in all languages, and articles related to the guiding question.

The extracted data from the studies after pre-screening, by reading the title and summary of each article, were author/year, title, design and country/language. Thematic synthesis was performed, which contained information about the purpose, population and place of the study, and pertinent result for our research.

The procedures related to the search, selection and analysis of the articles were performed almost entirely by two examiners. When necessary, a third examiner was introduced to the investigation to solve cases of disagreement regarding the selection of the studies.

To evaluate the articles' methodological quality, the classification was used of scientific papers based on the design used in the generation of evidence ${ }^{12}$ as observed in Chart 1.

Chart 1 - Hierarchy of evidence. Brasília, DF, Brazil, 2018.

\begin{tabular}{|cl|}
\hline Level & \\
\hline I & Evidence from systematic review or meta-analysis of all relevant randomized controlled trials or \\
II. & Evidence from at least one well-designed randomized controlled trial \\
III. & Evidence from well-designed clinical trials without randomization \\
IV. & Evidence from well-designed cohort and case-control studies \\
V & Evidence from systematic review of descriptive and qualitative studies \\
VI. & Evidence derived from a single descriptive or qualitative study \\
VII & Evidence from expert opinion and/or expert committee report \\
\hline
\end{tabular}


Subsequent to the completion of these phases, the studies were evaluated, interpreted and synthesized. The results are presented descriptively and by flowcharts and tables to capture evidence on MDRPI in adults.

\section{RESULTS}

After searching the databases, 219 articles were retrieved. Of these, 15 articles remained, selected by manual search and evaluation of the exclusion criteria, according to the stages described in Figure 1. The results are presented in Chart 2.

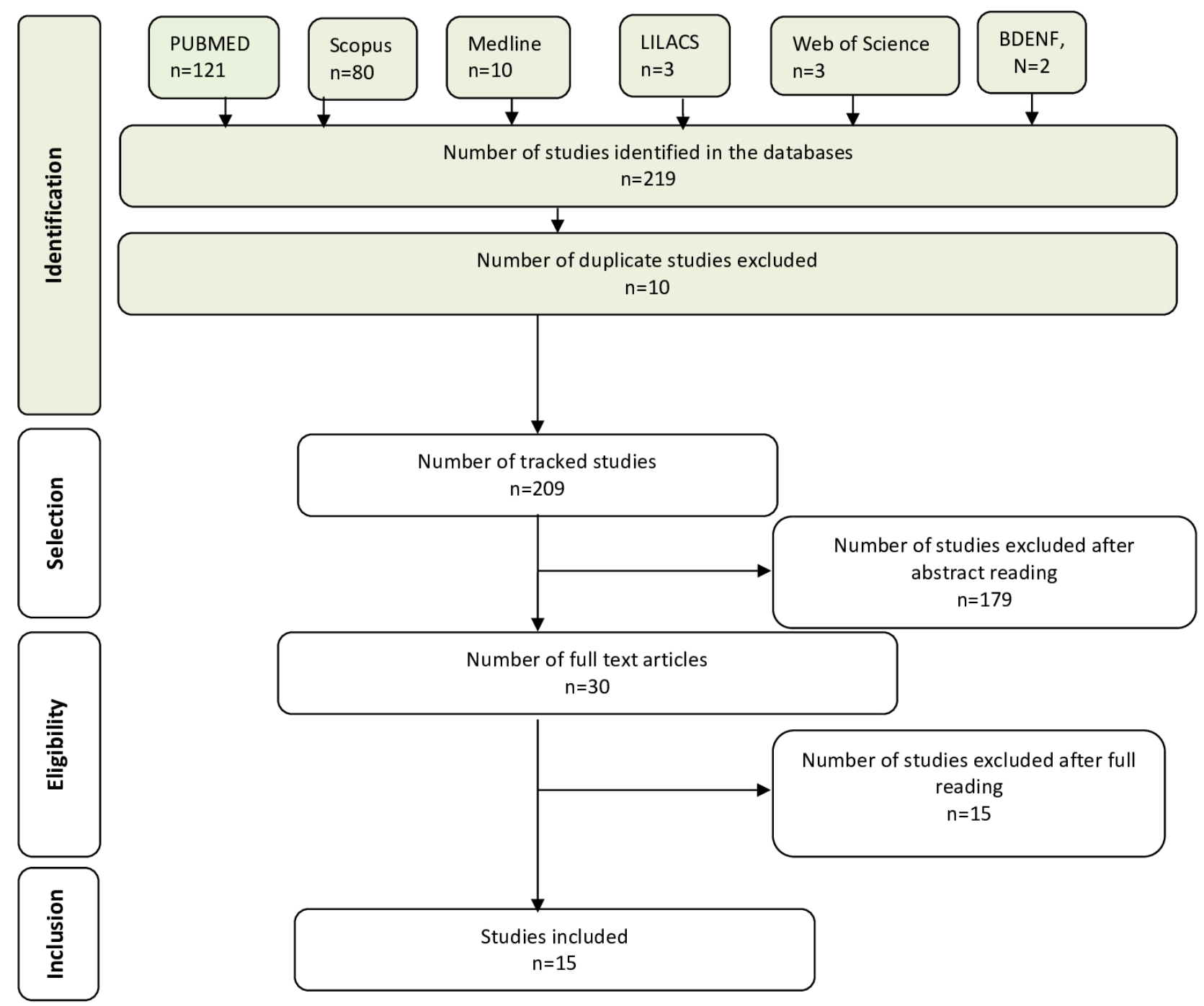

Figure 1 - Selection of the articles for integrative review. Brasília, DF, Brazil, 2018. 


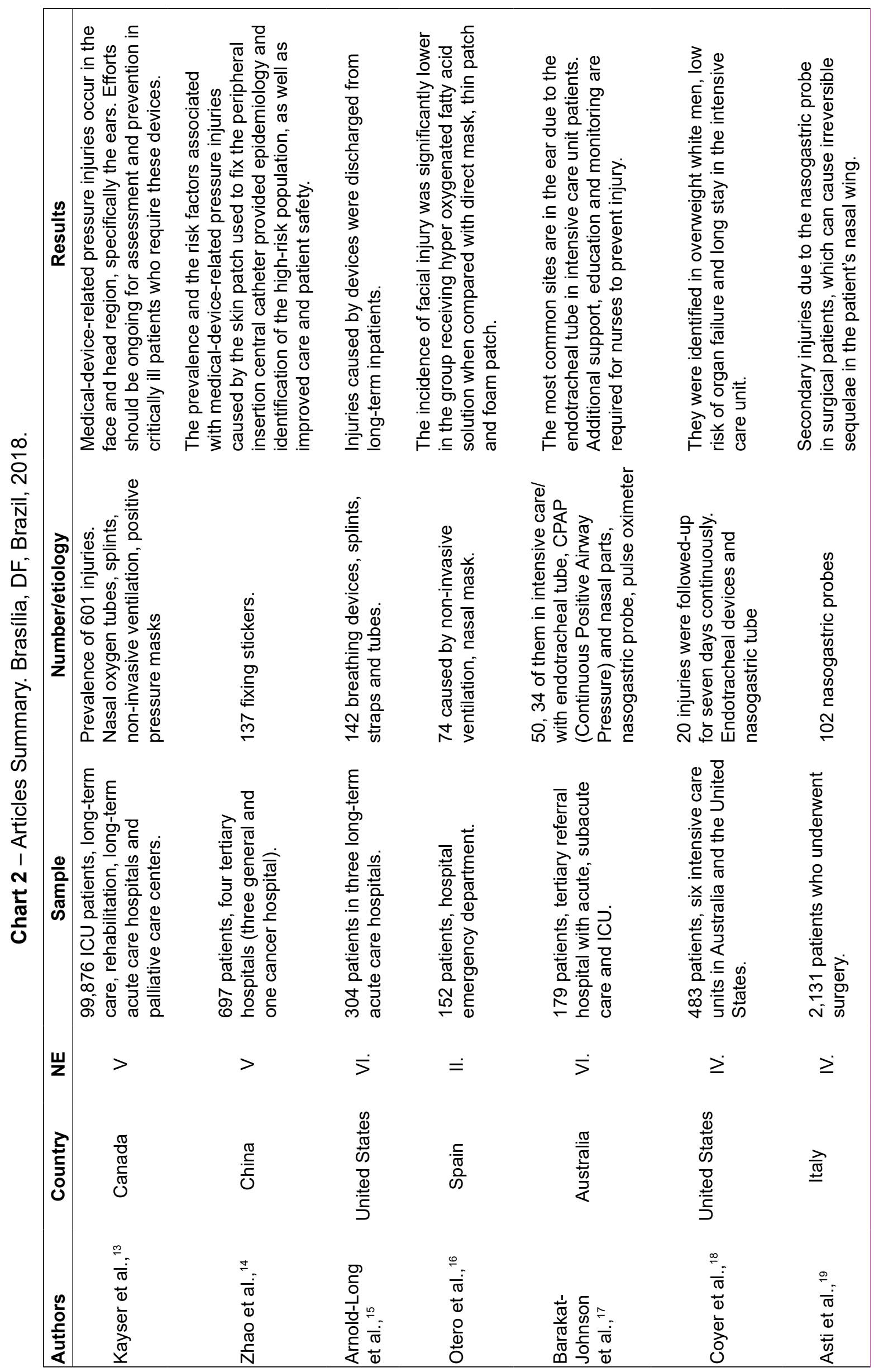




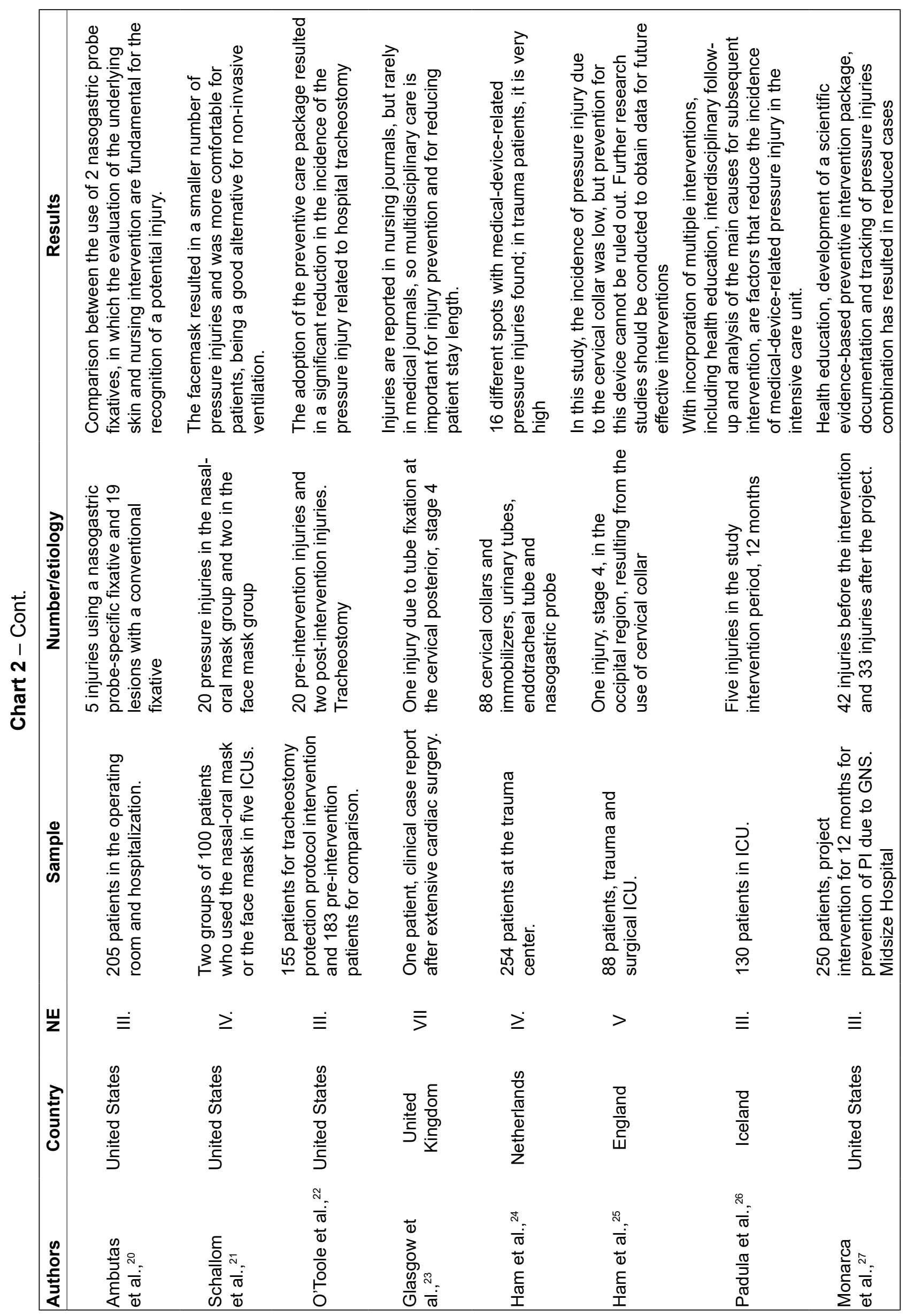


The research studies related to the topic focused abroad. Of the 15 articles included in this review, several Levels of Evidence were found, as observed in (Chart 3).

Chart 3 - Levels of evidence found in the articles included in the review. Brasília, DF, Brazil, 2018.

\begin{tabular}{|ccccccc|}
\hline Level I & Level II & Level III & Level IV & Level V & Level VI & Level VII \\
\hline 0 & $\begin{array}{c}\text { One } \\
\text { randomized } \\
\text { clinical trial }\end{array}$ & $\begin{array}{c}\text { Three well- } \\
\text { designed } \\
\text { clinical trials } \\
\text { without } \\
\text { randomization }\end{array}$ & $\begin{array}{c}\text { Four } \\
\text { prospective } \\
\text { cohort } \\
\text { studies }\end{array}$ & $\begin{array}{c}\text { Three } \\
\text { systematic } \\
\text { review of } \\
\text { descriptive } \\
\text { studies }\end{array}$ & $\begin{array}{c}\text { Two } \\
\text { descriptive } \\
\text { studies }\end{array}$ & $\begin{array}{c}\text { A case report } \\
\text { study }\end{array}$ \\
\hline
\end{tabular}

\section{DISCUSSION}

Studies show that the MDRPIs are common in adults, especially in the elderly, in which capillary fragility, among other changes, influences the development of skin lesions. Other observed factors include length of stay, critically ill patients or those requiring any type of medical device are more susceptible. Numerous medical devices have been associated with skin lesions, especially respiratory, feeding, and orthopedic ones, tubes, oximeters, neck collars, patches and nasogastric probes.

A study from retrospective data available from the International Pressure Ulcer Prevalence, created in 1989 to conduct the Pressure Injury Prevalence Survey, included 102,865 adult patients;99,876 had complete data and were the focus of the analysis. The overall prevalence of PI was $7.2 \%(n=7,189)$ and that of MDRPI was $0.60 \%(n=601) ; 58 \%$ were in stages 1 or 2 (superficial) and $22 \%$ in stages 3 and 4 , or were unclassifiable. The most common anatomical locations were the ears (29\%) and the feet (12\%). The most common devices associated were nasal oxygen tubes (26\%), other (19\%), splints (12\%), and continuous positive pressure/two-level positive pressure masks $(9 \%){ }^{13}$

These epidemiological data are essential indicators of the quality of the care provided and are used as a tool for evaluating and proposing new strategies and protocols for their prevention. ${ }^{28}$

Another important issue is the differentiation between $\mathrm{PI}$ and MDRPI. PI is more related to immobility, localization and bony prominences; MDRPI, on the other hand, often mirrors the device location. Thus, it is crucial that the nursing practice includes prevention to reduce the risk of the patient developing these injuries by focusing on evidence-based practices. ${ }^{29}$

$\mathrm{PI}$ also differs from MDRPI in that the devices are well adhered to the fixation location, and make it difficult to observe the underlying skin. This long-term contact with skin and mucous membranes is a risk factor for lesion generation. At the time of care, he professionals should carefully observe the place and make changes of fixation, leaving the place always dry and free of dirt. ${ }^{14}$

In a retrospective descriptive study at three long-term care facility units, which examined 304 adult patients in the United States,142 MDRPIs were observed, totaling 47\%, and stage 2 had 58 cases $(51 \%)$. The most frequently associated devices were respiratory (endotracheal tube, continuous positive airway pressure and positive airway pressure at two levels), splints or support and tubes. The most common location was the ear, which is thinly covered with cartilage and develop wounds quickly. ${ }^{15}$

Thus, medical devices cannot be considered harmless in contributing to the development of a $\mathrm{PI}$, especially a full thickness injury. Although medical and fixation devices are required, the nursing team should dispense their care, based on scientific evidence, to prevent such injuries, taking care to observe the proper fit, the effective need for the device, and the safety of medical devices as well as the appropriate implementation of prevention strategies. ${ }^{30}$ 
Regarding critically ill patients, an increased risk of lesion formation due to poor tissue perfusion caused by vasoactive drugs was observed in the group of patients receiving vasoactive drugs (54.8\%) when compared to people who did not receive (47.5\%). The incidence of two or more MDRPIs the same patient was $15.2 \%$ in the vasoactive drug group, and $12.7 \%$ in the non-drug patients. ${ }^{16}$

In addition, the lack of movement, inherent to the use of sedatives or inability to reposition, is visualized in critically ill patients, being important the constant inspection of the skin. In a study conducted with 179 patients, 21 cases of ear injuries resulting from endotracheal tube fixation were observed. The nurses reported that the fixation behind the ear was not an area they routinely inspected. ${ }^{17}$

Importantly, the number of devices present in the patients also increases the risk of injury. Patients who developed the lesions had a mean of six to eight devices installed. This number of devices is observed in critically ill patients. The most aggressive devices were the endotracheal tube and the nasogastric probe. ${ }^{18}$

In the critical patient context, with the use of multiple medical devices, use of vasoactive and sedative drugs, which influence the increased risk for the generation of MDRPIs and other injuries, it is worth highlighting the need for an interdisciplinary approach to establish shared responsibility for care, awareness of emerging problems and to promote quality-based care. ${ }^{31}$

A study conducted in Italy shows a prevalence of $4.8 \%$ of lesions in the nostrils. The pressure in the nostril due to the tube and its fixation causes severe tissue damage and evolution to necrosis, especially in patients with prolonged anesthetic duration. ${ }^{19}$

A non-randomized descriptive study compared the incidence of MDRPI with the use of conventional fixation ( $23 \%$ of cases) and a new type of more anatomically shaped adhesive ( $4 \%$ of cases) in the nostril. There was a significant decrease in lesions with the use of the anatomical fixator between the conventional fixator. The authors emphasize the need for evaluation and intervention of the nursing team for the recognition and prevention of injuries. ${ }^{20}$

The use of non-invasive mechanical ventilation is also observed in ICU patients, in a randomized clinical trial of 152 patients using NIV showed that 74 developed 87 MDRPIs at the nasal bridge, face, and chin. The incidence of injuries was $44 \%$ with the use of unprotected mask, $57 \%$ with protection of thin patch adhesive, $72 \%$ with foam patch adhesive and $23 \%$ with hyper oxygenated fatty acid. Thus, the protective factor of the use of hyper oxygenated fatty acid is observed. ${ }^{16}$

Emphasis is placed on the need for the interdisciplinary team to conduct patient assessment, including a review of all the devices used on the patient, appropriate skin protection, and treatment plan addressing the management of medical devices that may cause MDRPI. ${ }^{32}$

A comparative study on the use of nasal-oral mask and full-face mask revealed that the time to develop the lesions ranged from 1.25 to 74 hours on average after using the device. Facial masks are a reasonable alternative, compared to traditional nasal-oral masks, to decrease MDRPI cases due to their larger surface area for pressure distribution. ${ }^{21}$

Another device that comes as a risk factor for the development of injuries is tracheostomy. An incidence of MDRPI of $10.95 \%(n=20)$ was observed in 183 tracheostomy patients. Already after implantation of the protocol of hydrocolloid placement as protection, the incidence was $1.29 \%(n=2)$ in the group of 155 patients. The number of injuries decreased after the protocol was installed, which included hydrocolloid placement under the tracheostomy flange in the postoperative period, suture removal within seven days of the tracheostomy procedure, placement of a polyurethane foam dressing after suture removal and neutral head positioning. ${ }^{22}$

Stay length in the ICU makes the patient more susceptible to new infections and various adverse events. The mean length of hospital stay was longer in patients with MDRPI (28 to 59 days) vs. those without injury (22 to 35 days). In the specific case of stage 4 injuries, the patient was discharged with a longer hospitalization time of ten days or more..$^{22,24}$ 
In cases of critically ill patients resulting from trauma, MDRPI is developed during the first days of hospitalization, with a rate of $87.5 \%$. The explanation for the early onset is based on risk factors such as severity of the underlying disease, surgical interventions, malnutrition, ICU admission and pre-hospital immobilization. ${ }^{24}$

Some risk factors were found in a study conducted with 149 patients admitted to the ICU for trauma. At admission, 92\% of the patients were at risk for developing PI. According to the Braden scale (score 18), $12.5 \%$ had scores indicating high-to-high risk for PI. $25 \%$ of the trauma patients were overweight (body mass index $>27$ ). The severity score was high and the loss of consciousness level according to the Glasgow Coma scale was $<8$ in $22.7 \%$ of the patients. ${ }^{24}$

The Braden scale has been used to assess the risk of developing injuries. Another scale used for PI is Norton's, which classifies as high risk the patient who has evident immobility, neural and endothelial control of blood flow impaired by the diseases, making him/her more susceptible to ischemic tissue damage, and the use of a large number of medical devices for therapeutic and monitoring purposes. It is necessary to use more specific or jointly used tools to assess MDRPI risk factors. ${ }^{16,18,26}$

Another factor of vulnerability is age. The elderly, due to capillary fragility, have decreased collagen, elastin and perfusion, in addition to altered immune response, which reduces the healing capacity. Thus, the nurse should be aware of the use of adhesives as a dressing for central catheter devices, so that the material favors the observation of the underlying skin and does not increase the pressure and friction that the device already causes. ${ }^{12,25}$

It is important to emphasize the purpose and function of the medical device, and whether it is being used following the manufacturer's rules, as well as checking the size of the device - if it is appropriate for the patient - and if it is properly fixed to avoid unnecessary skin friction and excessive pressure on the underlying tissues. The next step is skin protection and spot surveillance every 4-6 hours, rotating the fixation places if possible. In the case of non-invasive ventilation, it is important to evaluate the skin every 12 hours for early identification of skin changes. ${ }^{16,21}$

An intervention project on quality improvement and decreased incidence of MDRPI found that the combination of education, development of a preventive intervention package based on evidence of scientific evidence, improved documentation and tracking of these injuries resulted in a reduction in the entire installation of injuries in the 12-month study period. ${ }^{27}$

Thus, it is possible to observe that there are several risk factors associated with injuries. Skin inspection, device repositioning and knowledge of the entire multidisciplinary team, since the generation and the triggering factors, are important premises to promote focused and quality care.

There are few publications based on data specifically related to MDRPI. Thus, this study constitutes an important step in Brazilian information and systematic investigation.

As usual in any integrative review research, limitations may arise, such as references that may have been overlooked if they were in other databases that were not included. MDRPI is a relatively new phenomenon in key terms, which can interfere with the complete capture of all available literature within a five-year time frame.

\section{CONCLUSION}

The articles analyzed portrayed the use of multiple medical devices in the care of critically ill hospitalized patients or in acute long-term care. Nevertheless, there are several risk factors for the development of medical-device-related pressure injuries, which include severity of the patient, length of stay, humidity, skin friction, age, and use of vasoactive drugs and sedatives, among others. In addition, the use of risk prediction scales, such as Braden's, is effective even if they are not unique to medical-device-related pressure injuries. 
The articles reflect that simply placing a medical device is already the starting point for the formation of pressure injuries related to the device. The materials, most of which have a rigid and non-malleable structure, are risk factors for predisposition. Thus, the first step towards prevention should be exploration in terms of identifying the types of devices that cause injury and evidence-based interventions, and disseminating information to the entire multidisciplinary team.

Given the large number of cases based on the international articles, practice-based studies are important, especially in Brazil. There are still gaps in the knowledge of the professionals, requiring constant updating, for the empowerment of theoretical knowledge and the best association with practice.

\section{REFERENCES}

1. Cavalcante $M L$, Borges CL, Moura AM, Carvalho RE. Indicators of health and safety among institutionalized older adults. Rev Esc Enferm USP [Internet] 2016 Jan [cited 2019 Jan 17];50(4):6029. Available from: https://dx.doi.org/10.1590/S0080-623420160000500009

2. National Pressure Ulcer Advisory Painel (NPUAP). Pressure Injury Staging Illustrations [Internet] Washington, DC(US): NPUAP; 2016 [cited 2019 Jan 17]. Available from: http://www.npuap.org/ resources/educational-and-clinical-resources/pressure-injury-staging-illustrations/

3. Borghardt A, Prado T, Araújo T, Rogenski N, Bringuente M. Evaluation of the pressure ulcers risk scales with critically ill patients: a prospective cohort study. RLAE [Internet] 2015 Feb [cited 28 Jan 2019];23(1):28-5. Available from: https://dx.doi.org/10.1590/0104-1169.0144.2521

4. Edsberg LE, Black JM, Goldberg M, McNichol L, Moore L, Sieggreen M. Revised National Pressure Ulcer Advisory Panel Pressure Injury Staging System: Revised pressure injury staging system. J Wound Ostomy Continence Nurs. [Internet] 2016 [cited 2019 Jan 17];43(6):585-97. Available from: https://dx.doi.org/10.1097/WON.0000000000000281

5. Apold J, Rydrych D. Preventing Device-Related Pressure Ulcers. J Nurs Care Quality. [Internet] 2012 [cited 2019 Jan 17];27(1):28-34. Available from: https://dx.doi.org/10.1097/NCQ.0b013e31822b1fd9

6. Olshansky K. The 10 most important questions concerning pressure ulcers and quality of care. Adv Skin Wound Care. [Internet] 2009 [cited 2019 Jan 17];21(11):505-8. Available from: https:// dx.doi.org/10.1097/01.ASW.0000323585.35228.4c

7. Vangilder C, Lachenbruch C, Algrim-Boyle C, Meyer S. The International Pressure Ulcer Prevalence $^{\mathrm{TM}}$ Survey. J Wound Ostomy Continence Nurs. [Internet] 2017 [cited 2019 Jan 17];44(1):20-8. Available from: https://dx.doi.org/10.1097/won.0000000000000292

8. Coyer FM, Stotts NA, Blackman VS. A prospective window into medical device related pressure ulcers in intensive care. Int Wound J. [Internet] 2014 [cited 2019 Jan 17];11:656-64. Available from: https://dx.doi.org/10.1111/iwj.12026

9. Parque $\mathrm{SH}$, Choi YK, Kang CB. Predictive validity of the Braden Scale for pressure ulcer risk in hospitalized patients. Int J Nurs Stud. [Internet] 2015 [cited 2019 Jan 17];24(3):102-13. Available from: https://dx.doi.org/10.1016/j.jtv.2015.05.001

10. Mendes KD, Silveira RC, Galvão CM. Integrative literature review: a research method to incorporate evidence in health care and nursing. Texto Contexto Enferm. [Internet] 2008 [cited 2019 Jan 17]; 17(4):758-64. Available from: https://dx.doi.org/10.1590/S0104-07072008000400018

11. Greenhalgh T. Como ler artigos científicos: fundamentos da medicina baseada em evidências. 2th ed. Porto Alegre, RS (BR): Artmed, 2005.

12. Melnyk BM, Fineout-Overholt E. Making the case for evidence based practice. In: Melnyk BM, Fineout-Overholt E. Evidence based practice in nursing \& health care. A guide to best practice. Philadelphia (US): Lippincot Williams \& Wilkins; 2005. p. 3-24. 
13. Kayser SA, VanGilder CA, Ayello EA, Lachenbruch C. Prevalence and analysis of Medical Device-Related Pressure Injuries: Results from the International Pressure Ulcer Prevalence Survey. Adv Skin Wound Care. [Internet] 2018 [cited 2019 Jan 17];31(6):276-85. Available from: https://dx.doi.org/10.1097/01.asw.0000532475.11971.aa

14. Zhao H, He Y, Wei Q, Ying Y. Medical Adhesive-Related Skin Injury Prevalence at the Peripherally Inserted Central Catheter Insertion Site: A Cross-sectional, Multiple-Center Study. J Wound Ostomy Continence Nurs. [Internet] 2018 [cited 2019 Jan 17];45(1):22-5. Available from: https:// dx.doi.org/10.1097/won.0000000000000394

15. Arnold-Long M, Ayer M, Borchert K. Medical Device-Related Pressure Injuries in Long-term Acute Care Hospital Setting. J Wound Ostomy Continence Nurs. [Internet] 2017 [cited 2019 Jan 17]; 44(4):325-30. Available from: https://dx.doi.org/10.1097/won.0000000000000347

16. Otero D P, Domínguez DV, Fernández LH, Magariño AS, González VJ, Klepzing JV, et al. Preventing facial pressure ulcers in patients under non-invasive mechanical ventilation: a randomised control trial. J Wound Care. [Internet] 2017 [cited 2019 Jan 17];26(3):128-36. Available from: https:// dx.doi.org/10.12968/jowc.2017.26.3.128

17. Barakat-Johnson M, Barnett C, Wand T, White K. Medical device-related pressure injuries: An exploratory descriptive study in an acute tertiary hospital in Australia. J Tissue Viability. [Internet] 2017 [cited 2019 Jan 17]; 6(4)246-53. Available from: https://dx.doi.org/10.1016/j.jtv.2017.09.008

18. Coyer FM, Stotts NA, Blackman VS. A prospective window into medical device related pressure ulcers in intensive care. Int Wound J. [Internet] 2014 [cited 2019 Jan 17];11:656-64. Available from: https://dx.doi.org/10.1111/iwj.12026

19. Asti E, Sironi A, Milito P, Bonavina G, Bonitta G, Bonavina L. Prevalence and risk factors of nasal pressure ulcers related to nasogastric intubation: an observational study. Eur Surg. [Internet] 2017 [cited 2019 Jan 17];49:171-4. Available from: https://dx.doi.org/10.1007/s10353-017-0476-y

20. Ambutas S, Staffileno BA, Fogg L. Reducing nasal pressure ulcers with an alternative taping device. Medsurg Nurs. [Internet] 2014 [cited 2019 Jan 17];23(2):96-100. Available from: https:// europepmc.org/abstract/med/24933786

21. Schallom M, Cracchiolo L, Falker A, Foster J, Hager J, Morehouse T, et al. Pressure ulcer incidence in patients wearing nasal-oral versus full-face noninvasive ventilation masks. Am J Crit Care. [Internet] 2015 [cited 2019 Jan 17]; 24(4):349-56. Available from: https://dx.doi. org/10.4037/ajcc2015386

22. O'Toole TR, Jacobs N, Hondorp B, Crawford L, Boudreau LR, Jeffe J, et al. Prevention of tracheostomy-related hospital-acquired pressure ulcers. Otolaryngol Head Neck Surg. [Internet] 2017 [cited 2019 Jan 17]; 156(4):642-51. Available from: https://dx.doi.org/10.1177/0194599816689584

23. Glasgow D, Millen IS, Nzewi OC, Varadarajaran B. Device-related atypical pressure ulcer after cardiac surgery. J Wound Care. [Internet] 2014 [cited 2019 Jan 17];23(8):383-4, 386-7. Available from: http://dx.doi.org/10.12968/jowc.2014.23.8.383

24. Ham WH, Schoonhoven L, Schuurmans MJ, Leenen LP. Pressure ulcers in trauma patients with suspected spine injury: a prospective cohort study with emphasis on device-related pressure ulcers. Int Wound J. [Internet] 2016 [cited 2019 Jan 17];14(1):104-11. Available from: https:// dx.doi.org/10.1111/iwj.12568

25. Ham HW, Schoonhoven LL, Galer AA, Shortridge-Baggett LL. Cervical collar-related pressure ulcers in trauma patients in intensive care unit. J Trauma Nurs. [Internet] 2014 [cited 2019 Jan 17];21(3):94-102. Available from: https://dx.doi.org/10.1097/jtn.0000000000000046

26. Padula CA, Paradis H, Goodwin R, Lynch J, Hegerich-Bartula D. Prevention of Medical DeviceRelated Pressure Injuries Associated with Respiratory Equipment Use in a Critical Care Unit: 
A Quality Improvement Project. J Wound Ostomy Continence Nurs. [Internet] 2017 [cited 2019 Jan 17]; 44(2):138-41. Available from: https://dx.doi.org/10.1097/won.0000000000000311

27. Monarca MC, Marteka P, Breda K. Decreasing incidence of medical device-related pressure injuries in a small community hospital a quality improvement project. J Wound Ostomy Continence Nurs. [Internet] 2018 [cited 2019 Jan 17];45(2):137-40. Available from: https://dx.doi.org/10.1097/ won. 0000000000000419

28. Strazzieri-Pulido KC, González CV, Nogueira PC, Padilha KG, Santos VL. Pressure injuries in critical patients: Incidence, patient-associated factors, and nursing workload. J Nurs Management. [Internet] 2019 [cited 2019 Jan 17];27(2):301-10. Available from: https://dx.doi.org/10.1111/ jonm.12671

29. Black J, Alves P, Brindle CT, Dealey C, Santamaria N, Call E, et al. Use of wound dressings to enhance prevention of pressure ulcers caused by medical devices. Int Wound J. [Internet] 2015 [cited 2019 Jan 17]; 12(3):322-7. Available from: https://dx.doi.org/10.1111/iwj.12111

30. Arnold-Long M, Ayer M, Borchert K. Medical device-related pressure injuries in long-term acute care hospital setting. J Wound Ostomy Continence Nurs. [Internet] 2017 [cited 2019 Jan 17];44(4):325-330. Available from: https://dx.doi.org/10.1097/won.0000000000000347

31. Padula CA, Paradis H, Goodwin R, Lynch J, Hegerich-Bartula D. Prevention of medical devicerelated pressure injuries associated with respiratory equipment use in a Critical Care Unit. J Wound Ostomy Continence Nurs. [Internet] 2017 [cited 2019 Jan 17];44(2):138-41. Available from: https://dx.doi.org/10.1097/WON.0000000000000311

32. Alves P, Eberhardt TD, Soares RS. Differential diagnosis in pressure ulcers and medical devices. Česká A Slovenská Neurologie A Neurochirurgie. [Internet] 2017 [cited 2019 Jan 17];80:29-35. Available from: https://dx.doi.org/10.14735/amcsnn2017S29 


\section{NOTES}

\section{CONTRIBUTION OF AUTHORITY}

Conception of the study: Cavalcanti EO.

Data collection: Cavalcanti EO.

Analysis and interpretation of data: Cavalcanti EO.

Discussion of the results: Cavalcanti EO.

Writing and/or critical review of content: Kamada I.

Review and final approval of the final version: Kamada I.

\section{FUNDING INFORMATION}

Centro Universitário Euroamericano - UNIEURO-DF

\section{CONFLICT OF INTEREST}

There is no conflict of interest.

\section{HISTORICAL}

Received: October 14, 2018.

Approved: March 01, 2019.

\section{CORRESPONDENCE AUTHOR}

Euni de Oliveira Cavalcanti

euni.cavalcanti@hotmail.com 